\title{
Investigating the Performance of Islamic Banks in Bangladesh
}

\author{
Md. Ibrahim ${ }^{1}$, Kazi Deen Mohammad ${ }^{2}$, Nazamul Hoque ${ }^{1} \&$ Mohammad Aktaruzzaman Khan $^{1}$ \\ ${ }^{1}$ Department of Business Administration, International Islamic University Chittagong, Bangladesh \\ ${ }^{2}$ Department of Quranic Sciences, International Islamic University Chittagong, Bangladesh \\ Correspondence: Md. Ibrahim, Department of Business Administration, International Islamic University \\ Chittagong, Bangladesh. E-mail: ibrupom@yahoo.com
}

Received: June 26, 2014 Accepted: September 3, 2014 Online Published: October 30, 2014

doi:10.5539/ass.v10n22p165 URL: http://dx.doi.org/10.5539/ass.v10n22p165

\begin{abstract}
Around the world Islamic banking system is getting popularity gradually due to its multidimensional benefits. Consequently, many tradition banks have been converted (such as FSIBL and EIBBL) into Islamic Sharia'h based banks for the superiority of Islamic banking system. Thus, it is the curiosity of the investors, depositors, researchers and policy makers to know the performance of Islamic banks operating in Bangladesh. So, taking secondary data from the annual reports of the sample banks, the study has evaluated the performance of six Islamic banks listed at both Dhaka Stock Exchange (DSE) \& Chittagong Stock Exchange (CSE) in terms of deposit; investment; foreign remittance collection; earnings per share (EPS); dividend declaration; dividend payout ratio; price earnings ratio $(\mathrm{P} / \mathrm{E})$ and net asset value (NAV). The study found that six Islamic banks have performed very well. Especially; Islami Bank Bangladesh Ltd. has shown outstanding performance in terms of every indicator. It is expected that the study will not only help the investors and depositors to make their decisions in more efficient way but also; it will motivate non-Islamic banks to convert their business mode according to Islamic Sharia'h.
\end{abstract}

Keywords: Islamic bank, performance, deposit, investment, earning per share (EPS)

\section{Introduction}

The Islamic financial law has long history but Islamic banking and finance industry came into existence with profit and loss sharing investment by Egypt's Mit Ghamr Saving Banks in 1963. After official existence Islamic banking has grown in the area of finance, banking, insurance, mortgage, and assets management business with annual growth rate of $10-15 \%$. But actual development in Islamic banking is started after 1970 with new investment techniques, strategies and product development (Steward, 2008). Dubai Islamic Bank (DIB) is known as world first Islamic bank it was formed in 1975. Currently it has 48 branches which great services. DIB offers higher returns than conventional banking system as well they provide auto, home and personal finance products (Platt, 2008).

The commercial banking system dominates Bangladesh's financial sector. Bangladesh Bank is the Central Bank of Bangladesh and the chief regulatory authority in the sector. After the independence, banking industry in Bangladesh started its journey with 6 nationalized commercialized banks, 2 State owned specialized banks and 3 Foreign Banks. In the 1980's banking industry achieved significant expansion with the entrance of private banks. Now, banks in Bangladesh are primarily of two types Scheduled Banks and Non-Scheduled Banks. There are 56 Scheduled Banks in Bangladesh. The Scheduled Banks are composed of 4 State Owned Commercial Banks; 4 Specialized Banks; 39 Private Commercial Banks of which 31 are Conventional \& 8 are Islamic Sharia'h based; 9 Foreign Commercial Banks. There are now 4 Non-Scheduled Banks in Bangladesh (Bangladesh Bank, 2014).

Bangladesh has two Stock Exchanges, Dhaka Stock Exchange (DSE), established in 1954 where trading is conducted by Computerized Automated Trading System and Chittagong Stock Exchange (CSE), established in 1995 which is also conducted by Computerized Automated Trading System (SEC). There are 30 Commercial banks have been listed at both Stock Exchange (DSE \& CSE) in Capital market of Bangladesh. Among the 30 banks, 23 are conventional and 07 are Islamic banks. At present, all domestic private Islamic banks are listed in capital market of Bangladesh, except Union Bank Limited. Few private commercial banks are yet to be enlisted. Only one State Owned Commercial Banks name as Rupali Bank Limited is listed in capital market of Bangladesh. No Specialized Banks and Foreign Commercial Banks are listed yet now. 
Islamic banking is based on Islamic Sharia'h Law which provides all solutions of financial problems as per the Islamic guidelines. According to Islamic law, interest is totally prohibited in Islam because interest has lot of bad effects on society such as it reduces the earning capacity, purchasing power of the interest provider and it also increases poverty, unequal distribution of wealth and credit crisis in an economy. According to Usmani (2005) the main drawback in interest based system is financier has no concern with money when he gives an interest bearing loan to a client. But in Islamic financial contract cash money is not given to client, first of all they purchase the commodity and transfer to client then all profit and loss will be distributed between parties according to agreed terms and conditions (Usmani, 2005). It is concluded by these statements that investment in Islamic financial system is really helpful to economy due to its proper check and balance as well as it is helpful to enhance the businesses of the society.

In Bangladesh Islamic banking started its journey in 1983 with the opening of Islami Bank Bangladesh Limited. Compared to the conventional banks, Islamic banks in Bangladesh have shown relatively better performance in the areas of loan recovery and various other financial measures (Ahmed, Rahman, \& Ahmed, 2006; Ahmad \& Hassan, 2007). Following such acceptance of Islamic banks in Bangladesh, various private commercial banks and international banks in Bangladesh started offering various financial products/services in accordance with Islamic principles (Hassan, 1999) along with their tradition interest based banking services.

While Islamic banking has gained popularity in Bangladesh, there have hardly been researches that addressed the all Islamic banks taking more comprehensive variables. Most of the studies in the context of Islamic banking in Bangladesh have so far focused on comparative financial performance of banks and legal issues (e.g., Ahmad \& Hassan, 2007; Ahmed, Rahman, \& Ahmed, 2006; Alam, 2000; Hassan, 1999; Sarkar, 1999) taking a few samples and from narrower perspective. Because, a comprehensive research is required not only for depositors, investors, policy makers and researchers but also for all stakeholders with a view to disseminate the real information. Especially; the knowledge of consumer motivations for choosing Islamic versus conventional banking services is very essential (Dusuki \& Abdullah, 2007).

Indeed, In Islam, business is an Ibadah (worship) and is recommended, whereas; riba (interest) is prohibited. From business point of view, Islamic bank is not only a firm but also a moral trustee of the depositors where deposits are trust given to banking firm. It is naturally expected that as a custodian of trust for the depositors' deposits, Islamic bank is likely to be more liquid and become more solvent compared to its counterpart conventional banks (Hassan \& Kabir, 1999). According to Islamic ethics, the Islamic bank management is accountable to the depositors in this world and the world hereafter for their failure to keep the trust entrusted upon them. It is, therefore, expected that the liquidity and solvency ratio of the Islamic bank will be higher than conventional banks (Samad \& Hassan, 2000). Thus, Evaluation of bank performance is important for all parties: depositors, bank managers and regulators. In a competitive financial market bank performance provides signal to depositor-investors whether to invest or withdraw funds from the bank. Similarly, it flashes direction to bank managers whether to improve its deposit service or investment service or both to improve its finance. Regulator is also interested to know for its regulation purposes (Samad \& Kabir, 1998).

Almost all commercial banks in Bangladesh today are under great pressure to meet the interests of their stockholders, employees, depositors, borrowers and customers. Most of the Islamic banks have grown in recent years, more and more of them have been forced to turn to the money and capital markets to raise funds by selling stocks, bonds and other financial instruments and banking products. Besides these, they have been engaging themselves in lots of non-banking activities like brokerage house function and merchant banking. As the numbers of investors in Dhaka Stock Exchange (DSE) are increasing day by day, a huge numbers of investors of capital markets are showing their interest to purchase and sell the share of different Islamic banks. But, there are very few studies which have been conducted on the performance of Islamic banks taking many essential variables so that the stakeholders can get sufficient information for making different types of decisions. Thus, in this paper a thorough investigation is done on the Performance of Islamic banks of Bangladesh in terms of deposit; investment; foreign remittance collection; earnings per share (EPS); dividend declaration; dividend payout ratio; price earnings ratio $(\mathrm{P} / \mathrm{E})$ and net asset value $(\mathrm{NAV})$.

\section{Rationale of the Study}

In any economy, money market and capital is regarded as an economic barometer which are inter related and interdependent. Indeed, without well-functioning money market, capital market also suffers severely (Demirguc-Kunt \& Levine, 2001). Therefore, the efficiency of money market in is highly needed to protect the interests of depositors and investors in general and all stakeholders in particular. If money market works as a complete safeguard, it will protect the interest of stakeholders and since banks are the very important members 
of money market, the effective roles of banks are highly required. Indeed, on the basis of the performance of money market the vibrant capital market is largely dependent which will ultimately help in expediting the growth of the economy through industrialization (Mamun, Hoque, \& Mamun, 2013). Since, Islamic banking system is getting popularity in the world it is the curiosity of the researchers to know the performance of Islamic banks of Bangladesh. The rationality lies in the fact that there is no comprehensive study which is undertaken to know the performance of Islamic banks operating in Bangladesh.

\section{Literature Review}

A brief review of literature has been conducted to identify factors for analyzing the performance of Islamic banks operating in Bangladesh. Safiullah (2010) said that the performance of interest-free Islamic banks in business development, profitability, liquidity and solvency is superior to that of interest-based conventional banks. Indeed, in today's world, bankers and their competitors are under great pressure to perform well all the time (Roes et al., 2005). But what does it mean by the word perform when it comes to banks and other financial service providers? In this case performance refers to how adequately a bank or other financial firm meets the objectives of stockholders (owners), employees, depositors, and other creditors, and borrowing customers. At the same time, these financial firms must find a way to keep government regulators satisfied so that their operating policies, loans, and investments are sound, protecting the public interest. The success or lack of success of these institutions in meeting the expectations of others is usually revealed by a careful and through analysis of their financial statements. According to Samad \& Hassan (2000) the evaluation of bank performance is important for all parties: depositors, bank managers and regulators. In a competitive financial market bank performance provides signal to depositors and investors whether to invest or withdraw funds from the bank. Similarly, it flashes direction to bank managers whether to improve its deposit service or loan service or both to improve its finance. Regulator is also interested to know for its regulation purposes. Generally, better performance of banks mean that the banks are growing from the stand point of investment and deposits along with some other very key indicators like high EPS, lower P/E ratios, dividend payout ratio, Net assets value(NAV), mode(cash/stock) of dividend declaration, stability of share price and performance in foreign remittance collection.

If any bank failed to maintain positive EPS trend, then according to (Samuel et al., 2001), negative returns follow dividend omission. This situation decreases the current market price of the share. Campbell \& Shiller (1988) says that long historical averages of real earnings help forecast present values of future real dividends. The total value of a bank's assets less the total value of its liabilities is its net asset value (NAV). For valuation purposes, it is general to divide net assets by the number of shares in issue to give the net assets per share. This is the value of the assets that belong to each share, in much the same way that $\mathrm{P} / \mathrm{E}$ measures profit per share. NAV is useful for the valuation of shares in sectors where the value of a company comes from the assets it holds rather than the profit stream generated by the business. According to Clayton \& MacKinnon (2002) uninformed or noise traders push prices away from NAVs following the initial price moves cause by informed traders.

Indeed, investors consider several factors in investing funds in any particular securities of capital market, of which, the most important factor is the return from the investment in securities that typically depends on the dividend declaration in the stock market (Khan et al., 2011; Mamun et al., 2013). Company declares dividend in the form of cash and/ or stock with in the financial year (quarterly or biannually) to meet the expectations of investors considering the ability and strategy of the company (Mamun et al., 2013). Payout of dividend is important as it informs the investing public certainty about the financial well-being of the company concerned. Furthermore, company's dividend decision on a regular interval that involves with whether to payout earnings to shareholders is important as it helps avoid agency problem (Jensen \& Meckling, 1976). On the investors' side, those who are looking to secure current income invest their fund in securities of the companies that are paying high dividend on a regular basis. Companies having long-standing history of dividend payout would be negatively affected by reducing dividend distribution and would positively be affected by increasing the same. Furthermore, companies without a dividend history are generally viewed favorably when they declare new dividends (Jais et al., 2010).

According to Besley \& Brigham (2008) regular stock dividend policy decreases the market price. But if the commercial banks frequently offer stock dividend, the negative impact such as decrease in share price, loss of goodwill, dissatisfaction of shareholders, sales of share at discount and increase in internal fund can be arisen in future. According to Rozeff (1982) the investment policy influences dividend policy. The Price to Earnings ratio ( $\mathrm{P} / \mathrm{E}$ ratio) is one of many ratios used by investors to evaluate how expensive or cheap a stock is relative to its historical cost (Hasan \& Saimoon, 2011). The P/E looks at the relationship between the stock price and the company's earnings. Basu (1977) said that price-earnings ratios are indicators of the future investment performance of a security. The $\mathrm{P} / \mathrm{E}$ is the most popular metric of stock analysis. The $\mathrm{P} / \mathrm{E}$ gives an idea of what 
the market is willing to pay for the company's earnings. The higher the $\mathrm{P} / \mathrm{E}$ ratio, the more the market is willing to pay for the company's earnings. Some investors read a high $\mathrm{P} / \mathrm{E}$ as an overpriced stock and that may be the case, however it can also indicate the market has high hopes for this stock's future and has bid up the price. Conversely, a low P/E may indicate a "vote of no confidence" by the market or it could mean this is a sleeper that the market has overlooked.

\section{Objectives of the Study}

Following objectives were set for this research paper:

$>$ To evaluate the performance of Islamic banks listed in the capital market of Bangladesh.

$>$ To make a comparison among different Islamic banks from different variables.

$>$ To propose some policy recommendations for ensuring good performance of Islamic banks in the capital market of Bangladesh.

\section{Methodology}

All the listed Islamic banks at DSE \& CSE have been selected except ICB Islamic Bank Limited (ICBIBL) for conducting the research. The ICBIB has been dropped from the list of preference due to its association with Z category, which is the clear indicator of its poor operational efficacy (SEC Bangladesh, 1993). Different financial tools and techniques are used in the study. The study also considered some factors like deposit; investment; foreign remittance collection; earnings per share (EPS); dividend declaration; dividend payout ratio; price earnings ratio (P/E) and net asset value (NAV) for analyzing the performance. The study basically depends on the secondary data which were collected from the DSE Publications, library and information division of Dhaka Stock Exchange (DSE), newspapers and other online resources. Data were also collected from the annual reports of the sample banks during the year 2004 to 2013.

Table 1.

\begin{tabular}{ll}
\hline Name of the Selected Banks & Acronyms \\
\hline 1. Al-Arafa Islami Bank Limited & AIBL \\
2. Export Import Bank Bangladesh limited & EIBBL \\
3. First Security Islami Bank Limited & FSIBL \\
4. Islami Bank Bangladesh Limited & IBBL \\
5. Shahjalal Islami Bank Limited & SHIBL \\
6. Social Islamic Bank Limited & SIBL \\
\hline
\end{tabular}

\subsection{Performance Analysis of Islamic Banks in Bangladesh}

For analyzing the performance of Islamic banks in Bangladesh, the study has considered some factors like deposit; investment; foreign remittance collection; earnings per share (EPS); dividend declaration; dividend payout ratio; price earnings ratio $(\mathrm{P} / \mathrm{E})$ and net asset value $(\mathrm{NAV})$.

As per SEC rules of Bangladesh (1993) when any company declares dividend at least $10 \%$ stock and cash or both annually or interim, the company's share is in A category and declared dividend $5 \%$ to below $10 \%$ the company's share is in B category and declared no dividend at the year end, the company's share is in Z category. All Islamic Banks are in A-Category Share at DSE, except ICBIB is Z-category.

In terms of paid up capital two banks, namely IBBL and EIBBL are on the top position with authorized capital of Tk. 20,000 million. Among these Islamic banks, IBBL has the highest paid-up capital is Tk. 14,636 million. The important thing is that all listed Islamic banks are the member of Central Depository Bangladesh Limited (CDBL), hence the share of these banks are in electronic or D-mat (De-materialize) format. There is no significant government participation in the ownership of any Islamic bank listed at DSE. Sponsor/Directors ownership is approximately $50 \%$ of all Islamic banks except the SIBL. But the public holdings of the share are huge for EIBBL and SHIBL. Institutional participations in the ownership of different Islamic banks are also lower. IBBL has the highest institutional participations among these seven Islamic Banks (Appendix Table 1).

\subsection{Performance of Islamic Banks in Terms of Deposit}

Deposit is very important for a bank. Indeed, the main source of capital of investment is deposit in a bank. It has been found that the present (2013) deposit all six Islamic banks is TK 111184.2 core of which IBBL has TK 
47,314.1 core which is the highest deposit not only among the Islamic banks but also among all the private commercial banks of Bangladesh including traditional and Islamic banks, whereas; the total deposit of all other banks is TK 63870.1 core. It means IBBL lonely has $42.55 \%$ deposit and the other five banks all together have $57.45 \%$ of deposit (Appendix Table 2). On the contrary, the average growth of deposits of all Islamic banks is $28.02 \%$ and AIBL and FSIBL have the highest average growth in deposit with $35.75 \%$ and $32.97 \%$ respectively (Appendix Table 3).

\subsection{Performance of Islamic Banks in Terms of Investment}

It has been found that the present (2013) investment of all six Islamic banks is TK 96259.7 core of which IBBL has TK 40680.5 core which is the highest investment not only among the Islamic banks but also among all the private commercial banks of Bangladesh including traditional and Islamic banks whereas, the total investment of all other banks is TK 55579.2 core. It means IBBL lonely has $42.26 \%$ investment and the other five banks all together have $57.74 \%$ of investment (Appendix Table 4). On the contrary, the average growth of investment of all Islamic banks is $27.2183 \%$ and AIBL and FSIBL have the highest average growth in investment with $34.92 \%$ and $32.16 \%$ respectively (Appendix Table 5).

\subsection{Performance of Islamic Banks in Terms of Foreign Remittance Collection}

It has been found that the present (2013) foreign remittance collection of all six Islamic banks is TK 29872.5 core of which IBBL has TK 28695.6 core which is the highest foreign remittance collection not only among the Islamic banks but also among all the private commercial banks of Bangladesh including traditional and Islamic banks whereas, the total foreign remittance collection of all other banks is TK 1176.9 core. It means IBBL lonely has collected $96.06 \%$ of foreign remittance and the other five banks all together have $3.94 \%$ of foreign remittance collection (Appendix Table 6). On the contrary, the average growth of foreign remittance collection of all Islamic banks is $58.45 \%$. FSIBL and AIBL have the highest average growth in foreign remittance collection with $123.27 \%$ and $64.69 \%$ respectively (Appendix Table 7).

\subsection{Performance of Islamic Banks in Terms of Earnings per Share (EPS)}

Earnings per share are usually considered to be the single most important variable in determining a share's price (Hasan \& Saimoon, 2011). It is also a major component used to calculate the price-to earnings valuation ratio. It is also used as a key indicator in measuring the performance of an organization regardless of its types. The table (Appendix Table 8) shows the average earnings per share (EPS) of all Islamic Banks during the year 2004 to 2013 is $3.24 \%$. In the table it is seen that the average EPS of IBBL is the highest having 4.85 which is higher than the average and it is consistent and the average EPS of AIBL is Tk. 3.65 which is also consistent during the year 2004 to 2013 which indicates their continuous better performance. The average EPS of EIBBL is Tk. 4.14, which was inconsistent during the year 2004 to 2013. The EPS of EIBBL is gradually decreasing. This is the basic reason for which the market price of EIBBL has been fallen down. All other Islamic Banks have shown somehow stable EPS. Among the six Islamic Banks, IBBL has shown the highest average EPS Tk. 4.85 during the year 2004 to 2013 as well as IBBL has the highest EPS Tk. 3.45 in the year 2013. That's why the present share price IBBL is comparatively higher than others Islamic Banks.

\subsection{Performance of Islamic Banks in Terms of Dividend Declaration}

It has been found (Appendix Table 9) that among the Islamic banks the dividend declaration of IBBL is consistent. The IBBL declared dividend averagely $25.5 \%$ during the year 2004 to 2013 which is higher than that of average $20.08 \%$ of all Islamic banks. The IBBL was declared dividend in both stock and cash mode which is considered as the good dividend policy for the both investors and bank. It is the expectation of investors that the bank will give their return in cash. The dividend declaration of AIBL and EIBBL are also consistent. The AIBL declared dividend averagely $23.4 \%$ and the EIBBL declared dividend averagely $25.8 \%$ during the year 2004 to 2013 which was also higher than the average of all banks. But AIBL and EIBBL declared dividend in stock mode, as a result their EPS \& NAV have been decreased gradually over the years. In the previous study it was found that the declaration of dividend in stock mode was profitable for all kinds of investors (Mamun et al., 2013). But we found that the EPS \& NAV of those banks decreased who declared dividend only in stock mode. The dividend declaration of SHIBL; FSIBL and SIBL are inconsistent during the period 2004-2013, as a result the share price of these banks were fluctuated. So, in declaring dividend, IBBL has shown more professionalism, as a result the share price of IBBL was consistent.

\subsection{Performance of Islamic Banks in Terms of Dividend Payout Ratio}

It is seen (Appendix Table 10) that among the six Islamic banks; IBBL has the lowest average dividend payout ratio (0.532) which indicates that IBBL has the highest retained earnings. It is also indicate that IBBL has the 
more opportunity to invest their retained earnings in different business sector. As a result, their total profit is gradually increasing over the year and the EPS of IBBL was consistent whereas, no. of shares was increased. On the other hand, SIBL has the highest dividend payout ratio having 0.677 which indicates that SIBL has the lowest retained earnings. It also indicates that SIBL has the less opportunity to invest their retained earnings in different sector. As a result, EPS of SIBL was decreased and inconsistent whereas, no. of shares was increased year by year. Dividend payout ratio of AIBL; EIBBL; SHIBL are also higher.

\subsection{Performance of Islamic Banks in Terms of Price Earnings Ratio (P/E)}

It is found (Appendix Table 11) that the average price earnings ratio (P/E) of IBBL, AIBL are 12.62 and 11.85 respectively which indicates that the EPS and the share price are more rationale and consistent. The average price earnings ratio (P/E) of EIBBL is 9.86 during the year 2004 to 2013 and the price earnings ratio $(\mathrm{P} / \mathrm{E})$ of EIBBL is 6 for the year 2013 which indicates that the EPS and the share price are more rationale but inconsistent. On the other hand the average price earnings ratio (P/E) of SIBL, FSIB and SHIBL are 21.32, 16.82 and 11.61 respectively during the year 2004 to 2013 and the price earnings ratio (P/E) of SIBL, FSIBL and SHIBL are 5.87, 8.03 and 4.52 respectively which indicates that the EPS and the share price was felt down tremendously. That's why most of the investors are loser to invest their money in SIBL, FSIBL, and SHIBL. P/E ratio is one of the important considering factors while making investment decision (Hasan \& Saimoon, 2011). Generally, investors choose lower $\mathrm{P} / \mathrm{E}$ while making investment decisions. The $\mathrm{P} / \mathrm{E}$ ratios of all Islamic banks are now below 10 which is the lower than the average 14.013. It indicates that the favorable investment opportunity is prevailed in buying the stock of Islamic banks.

\subsection{Performance of Islamic Banks in Terms of Net Asset Value (NAV)}

In the table (Appendix Table 12) it is seen that the average NAV of IBBL is Tk. 30.47 per share which is consistent and the average NAV of AIBL is Tk. 18.87 per share which is also consistent during the year 2004 to 2013 which indicates their continuous better performance. The average NAV of EIBBL is Tk. 18.75 per share and the average NAV of SIBL is Tk. 16.17 per share during the year 2004 to 2013. But the NAV of EIBBL is gradually decreased. All other Islamic Banks have shown somehow stable NAV. Among the six Islamic banks, IBBL has shown the highest average NAV Tk. 30.47 during the year 2004 to 2013 as well as IBBL has the highest NAV Tk. 29.92 per share in the year 2013. That's why the present share price of IBBL is comparatively higher than others Islamic Banks. The NAV of all Islamic banks are close to the market price of the share. So it simply indicates that the NAV of stock plays roles in determining the stock price.

\section{Policy Recommendations and Conclusion}

It has been found that from the different dimensions; the performance of IBBL is consistent and very good followed by AIBL. But, the performances of Islamic banks other than IBBL are not satisfactory in case of foreign remittance collection. Indeed, the performance is the outcome of various variables relating to deposit, investment, foreign remittance collection and dividend policy. It is found that the overall performance of all Islamic banks is satisfactory. It simply indicates that the future of Islamic banking system in Bangladesh is very bright. But for exploiting the market opportunity the Islamic banks must develop market driven strategy. Indeed, interest based banking system has created many problems in the society like economic discrimination and economic recession. Only Islamic banking system can create social and economic justice. For doing that, the policy makers should come forward in providing policy support and the bankers should gain the more trust of the depositors and investors through their transparent transactions. Indeed, trust is the foundation of business.

\section{References}

Ahmad, A. U. F., \& Hassan, M. K. (2007). Regulation and Performance of Islamic Banking in Bangladesh. Thunderbird International Business Review, 49(2), 251-277. http://dx.doi.org/10.1002/tie.20142

Ahmad, K. (2000). Islamic finance and banking: The challenge and Prospects. Review of Islamic Economics, 9, 57-82.

Ahmed, E., Rahman, Z., \& Ahmed, R. I. (2006). Comparative analysis of loan recovery among nationalized, private, and Islamic commercial banks of Bangladesh. BRAC University Journal, III(1), 35.

Alam, M. N. (2000). Islamic banking in Bangladesh: A case study of IBBL. International Journal of Islamic Financial Services, 1(4).

Basu, S. (1977). Investment performance of common stocks in relation to their price-earnings ratios: A test of the efficient market hypothesis. The Journal of Finance, 32(3), 663-682. http://dx.doi.org/10.1111/j.1540-6261. 1977.tb01979.x 
Besley, S., \& Brigham, E. F. (2008). Essentials of managerial finance; Cengage Learning (13th ed.). McGraw Hill, USA.

Campbell, J. Y., \& Shiller, R. J. (1988). Stock prices, earnings, and expected dividends. The Journal of Finance, 43(3), 661-676. http://dx.doi.org/10.1111/j.1540-6261.1988.tb04598.x

Clayton, J., \& MacKinnon, G. (2002). Departures from NAV in REIT pricing: The private real estate cycle, the value of liquidity and investor sentiment. Real Estate Research Institute, Working Paper.

Demirguc-Kunt, A., \& Levine, R. (2001). Bank-Based and Market-Based Financial Systems: Cross-Country Comparisons. Financial Structure and Economic Growth. MIT Press.

Dusuki, A. W., \& Abdullah, N. I. (2007). Why do Malaysian customers patronize Islamic banks? International Journal of Bank Marketing, 25(3), 142-160. http://dx.doi.org/10.1108/02652320710739850

Hasan, Z., \& Saimoon, A. (n. d.). Performance Analysis of Listed Private Commercial Banks in Dhaka Stock Exchange: An Empirical Study. Department of Banking Faculty of Business Studies University of Dhaka, 5(1), 146-155.

Hassan, M. K. (1999). Islamic banking in theory and practice: The experience of Bangladesh. Managerial Finance, 25(5), 60-113. http://dx.doi.org/10.1108/03074359910765966

Jais, M., Karim, B. A., Funaoka, K., \& Abidin, A. Z. (2010). Dividend Announcements and Stock Market Reaction. MPRA Paper No. 19779, posted 12.

Jensen, M. C., \& Meckling, W. H. (1976). Theory of the Firm: Managerial Behavior, Agency Costs and Ownership Structure. Journal of Financial Economics, 3(4), 305-360. http://dx.doi.org/10.1016/0304-405X (76) $90026-X$

Khan, K. I., Aamir, M., Qayyum, A., Nasir, A., \& Khan, M. I. (2011). Can Dividend Decisions Affect the Stock Prices: A Case of Dividend Paying Companies of KSE. International Research Journal of Finance and Economics, 76.

Mamun, A., Hoque, N., \& Mamun, A. M. A. (2013). Stock Price Reaction to Dividend Announcement: The Case of Bangladesh Capital Market. Journal of Economics and Sustainable Development, 4(8), 89-98.

Platt, G. (2008). Islamic Financial Institutions Awards. Global Finance, 22(6), 7.

Retrieved May 10, 2014, from http://dsebd.org/companylistbyindustry.php?industryno=11

Retrieved May 12, 2014, from http://www.investopedia.com/terms/d/dividendreinvestmentplan.asp

Retrieved May 18, 2014, from http://www.bangladesh-bank.org/fnansys/bankfi.php

Retrieved May 18, 2014, from http://www.sec.gov.bd/

Roes, P. S., \& Hudgins, S. C. (2005). Bank Management and Financial Services (6th ed.). McGraw Hill Publications.

Rozeff, M. (1982). Growth, beta and agency costs as determinants of dividend payout ratios. Journal of financial Research, 5(3), 249-259. http://dx.doi.org/10.1111/j.1475-6803.1982.tb00299.x

Safiullah, M. (2010). Superiority of conventional banks \& Islamic banks of Bangladesh: A comparative study. International Journal of Economics and Finance, 2(3), 199-207. http://dx.doi.org/10.5539/ijef.v2n3p199

Samad, A., \& Hassan, M. K. (2000). The performance of Malaysian Islamic bank during 1984-1997: An exploratory study. Thoughts on Economics, 10(1-2), 7-26.

Samad, A., \& Kabir, H. M. (1998). The Performance of Malaysian Commercial Bank during 1984-1997: An Exploratory Study. International Journal of Commercial Financial Services, 1(3).

Samuel, H., Szewczyk, G. P., \& Tsetsekos, Z. Z. Z. (1997). Do Dividend Omissions Signal Future Earnings or Past Earnings? Journal of Investing, 6(1), 40-53. http://dx.doi.org/10.3905/joi.6.1.40

Sarkar, M. A. A. (1999). Islamic banking in Bangladesh: Performance, problems \& prospects. International Journal of Islamic Financial Services, 1(3).

Steward, M. (2008). Alternative agenda: Sharia-compliant investing-Balancing profit with religion: Professional Wealth Management.

Taqi, U. M. (2005). An Introduction to Islamic Finance. Pakistan: Maktaba Ma'Ariful Qur'an. 


\section{Appendix A}

Table A1. Integrated Information about all Islamic banks in the year 2013

\begin{tabular}{|c|c|c|c|c|c|c|c|c|}
\hline Acronyms & $\begin{array}{l}\text { Listing } \\
\text { Year }\end{array}$ & $\begin{array}{l}\text { Market } \\
\text { Category }\end{array}$ & $\begin{array}{l}\text { Electronic } \\
\text { Share }\end{array}$ & $\begin{array}{l}\text { Authorized } \\
\text { capital (BDT } \\
\text { mn) }\end{array}$ & $\begin{array}{l}\text { Paid up } \\
\text { Capital } \\
\text { (BDT mn) }\end{array}$ & $\begin{array}{l}\text { Face } \\
\text { Value }\end{array}$ & $\begin{array}{l}\text { Market } \\
\text { Lot }\end{array}$ & $\begin{array}{ll}\text { No. } & \text { of } \\
\text { Securities }\end{array}$ \\
\hline AIBL & 1998 & A & YES & 15,000 & 9,470 & 10 & 250 & $946,958,501$ \\
\hline EIBBL & 2004 & A & YES & 20,000 & 11,566 & 10 & 100 & $1,156,634,782$ \\
\hline FSIBL & 2008 & A & YES & 10,000 & 4,114 & 10 & 100 & $411,438,720$ \\
\hline ICBIBL & 1990 & $\mathrm{Z}$ & YES & 15,000 & 6,647 & 10 & 500 & $664,702,300$ \\
\hline IBBL & 1985 & A & YES & 20,000 & 14,636 & 10 & 100 & $1,463,627,880$ \\
\hline SHIBL & 2007 & A & YES & 10,000 & 6,679 & 10 & 50 & $667,898,301$ \\
\hline SIBL & 2000 & A & YES & 10,000 & 7,031 & 10 & 250 & $703,141,564$ \\
\hline
\end{tabular}

Source: Created (based on different websites) \& annual reports.

Table A2. Deposits of Islamic banks during 2004-2013 (Tk. in core)

\begin{tabular}{|c|c|c|c|c|c|c|c|c|c|c|}
\hline Acronyms & 2004 & 2005 & 2006 & 2007 & 2008 & 2009 & 2010 & 2011 & 2012 & 2013 \\
\hline AIBL & 923.7 & 1164.4 & 1677.5 & 2300.9 & 2969.0 & 3835.6 & 5388.3 & 8218.7 & 11868.3 & 14098.1 \\
\hline EIBBL & 1907.8 & 2831.9 & 3503.2 & 4154.7 & 5758.7 & 7383.5 & 9494.5 & 10788.1 & 14037.0 & 16573.3 \\
\hline FSIBL & 1126.4 & 1401.2 & 1759.2 & 2350.4 & 2585.4 & 4242.3 & $5,634.4$ & 7814.5 & 10990.6 & 13952.1 \\
\hline IBBL & 8784.1 & 10777.9 & 13241.9 & 16632.5 & 20034.3 & 24429.2 & $29,193.5$ & 34185.4 & 41784.4 & 47314.1 \\
\hline SHIBL & 1276.4 & 1532.6 & 1809.0 & 2261.8 & 3428.0 & 4745.9 & 6296.5 & 8335.0 & 10217.6 & 9648.1 \\
\hline SIBL & 1346.0 & 1434.2 & 1604.7 & 1870.6 & 2206.6 & 2766.4 & 3983.3 & 5666.1 & 8109.1 & 9598.5 \\
\hline & \multicolumn{9}{|c|}{ Total deposit } & 111184.2 \\
\hline
\end{tabular}

Source: Created (based on DSE Websites) \& annual reports of the sample banks.

Table A3. Growth of deposits of Islamic banks, during 2004-2013

\begin{tabular}{llllllllllll}
\hline Acronyms & $\mathbf{2 0 0 5}$ & $\mathbf{2 0 0 6}$ & $\mathbf{2 0 0 7}$ & $\mathbf{2 0 0 8}$ & $\mathbf{2 0 0 9}$ & $\mathbf{2 0 1 0}$ & $\mathbf{2 0 1 1}$ & $\mathbf{2 0 1 2}$ & $\mathbf{2 0 1 3}$ & Mean & SD \\
\hline AIBL & $26.06 \%$ & $44.07 \%$ & $37.16 \%$ & $29.04 \%$ & $29.18 \%$ & $40.48 \%$ & $52.52 \%$ & $44.41 \%$ & $18.79 \%$ & $35.75 \%$ & 0.107 \\
EIBBL & $48.44 \%$ & $23.71 \%$ & $18.60 \%$ & $38.61 \%$ & $28.21 \%$ & $28.59 \%$ & $13.62 \%$ & $30.12 \%$ & $18.07 \%$ & $27.55 \%$ & 0.109 \\
FSIBL & $24.40 \%$ & $25.55 \%$ & $33.61 \%$ & $9.99 \%$ & $64.08 \%$ & $32.81 \%$ & $38.69 \%$ & $40.64 \%$ & $26.95 \%$ & $32.97 \%$ & 0.148 \\
IBBL & $22.70 \%$ & $22.86 \%$ & $25.61 \%$ & $20.45 \%$ & $21.94 \%$ & $19.50 \%$ & $17.10 \%$ & $22.23 \%$ & $13.23 \%$ & $20.62 \%$ & 0.037 \\
SHIBL & $20.07 \%$ & $18.06 \%$ & $25.03 \%$ & $51.56 \%$ & $38.45 \%$ & $32.67 \%$ & $32.38 \%$ & $22.59 \%$ & $-5.57 \%$ & $26.13 \%$ & 0.158 \\
SIBL & $6.55 \%$ & $11.89 \%$ & $16.57 \%$ & $17.96 \%$ & $25.37 \%$ & $43.99 \%$ & $42.25 \%$ & $43.12 \%$ & $18.37 \%$ & $25.12 \%$ & 0.144 \\
\multicolumn{6}{l}{ Average of deposit growth of Islamic Banks } & & & & & &
\end{tabular}

Source: Created (based on DSE Websites) \& annual reports of the sample banks.

Table A4. Investment of Islamic banks during 2004-2013 (Tk. in core)

\begin{tabular}{lllllllllll}
\hline Acronyms & $\mathbf{2 0 0 4}$ & $\mathbf{2 0 0 5}$ & $\mathbf{2 0 0 6}$ & $\mathbf{2 0 0 7}$ & $\mathbf{2 0 0 8}$ & $\mathbf{2 0 0 9}$ & $\mathbf{2 0 1 0}$ & $\mathbf{2 0 1 1}$ & $\mathbf{2 0 1 2}$ & $\mathbf{2 0 1 3}$ \\
\hline AIBL & 874.7 & 1147.4 & 1742.3 & 2290.6 & 2774.3 & 3613.4 & 5358.3 & 7771.5 & 10665.1 & 12571.5 \\
EIBBL & 1933.3 & 2604.6 & 3264.1 & 4019.5 & 5363.8 & 6861.0 & 9329.7 & 9969.9 & 11822.0 & 14384.7 \\
FSIBL & 964.8 & 1072.2 & 1364.6 & 1861.6 & 2509.5 & 3872.6 & 5212.4 & 6946.7 & 9630.4 & 11460.2 \\
IBBL & 7585.9 & 9364.4 & 11357.5 & 14492.1 & 18005.4 & 21461.6 & 26322.5 & 30584.1 & 37292.1 & 40680.5 \\
SHIBL & 1195.4 & 1367.3 & 1551.5 & 2061.7 & 3291.9 & 4395.8 & 6144.0 & 8059.2 & 9618.5 & 8570.6 \\
SIBL & 1288.7 & 1509.6 & 1531.3 & 1644.0 & 1995.1 & 2658.1 & 3668.0 & 5390.9 & 7602.5 & 8592.2 \\
Total investment & & & & & & & & & $\mathbf{9 6 2 5 9 . 7}$ \\
\hline
\end{tabular}

Source: Created (based on DSE Websites) \& annual reports of the sample banks. 
Table A5. Growth of investment of Islamic banks during 2004-2013

\begin{tabular}{lllllllllllll}
\hline Acronyms & $\mathbf{2 0 0 4}$ & $\mathbf{2 0 0 5}$ & $\mathbf{2 0 0 6}$ & $\mathbf{2 0 0 7}$ & $\mathbf{2 0 0 8}$ & $\mathbf{2 0 0 9}$ & $\mathbf{2 0 1 0}$ & $\mathbf{2 0 1 1}$ & $\mathbf{2 0 1 2}$ & $\mathbf{2 0 1 3}$ & Mean & SD \\
\hline AIBL & - & $31.18 \%$ & $51.85 \%$ & $31.47 \%$ & $21.12 \%$ & $30.25 \%$ & $48.29 \%$ & $45.04 \%$ & $37.23 \%$ & $17.88 \%$ & $34.92 \%$ & 0.117 \\
EIBBL & - & $34.72 \%$ & $25.33 \%$ & $23.14 \%$ & $33.44 \%$ & $27.91 \%$ & $35.98 \%$ & $6.86 \%$ & $18.58 \%$ & $21.68 \%$ & $25.29 \%$ & 0.092 \\
FSIBL & - & $11.13 \%$ & $27.27 \%$ & $36.42 \%$ & $34.80 \%$ & $54.32 \%$ & $34.60 \%$ & $33.27 \%$ & $38.63 \%$ & $19.00 \%$ & $32.16 \%$ & 0.123 \\
IBBL & - & $23.44 \%$ & $21.28 \%$ & $27.60 \%$ & $24.24 \%$ & $19.20 \%$ & $22.65 \%$ & $16.19 \%$ & $21.93 \%$ & $9.09 \%$ & $20.62 \%$ & 0.054 \\
SHIBL & - & $14.38 \%$ & $13.47 \%$ & $32.88 \%$ & $59.67 \%$ & $33.53 \%$ & $39.77 \%$ & $31.17 \%$ & $19.35 \%$ & $-10.89 \%$ & $25.93 \%$ & 0.198 \\
SIBL & - & $17.14 \%$ & $1.44 \%$ & $7.36 \%$ & $21.36 \%$ & $33.23 \%$ & $37.99 \%$ & $46.97 \%$ & $41.02 \%$ & $13.02 \%$ & $24.39 \%$ & 0.160 \\
\multicolumn{2}{l}{ Average of investment growth } & & & & & & & & & $\mathbf{2 7 . 2 1 8 3 \%}$ \\
\hline
\end{tabular}

Source: Created (based on DSE Websites) \& annual reports of the sample banks.

Table A6. Foreign remittance collection of Islamic banks, during 2004-2013 (Tk. in core)

\begin{tabular}{lllllllllll}
\hline Acronyms & $\mathbf{2 0 0 4}$ & $\mathbf{2 0 0 5}$ & $\mathbf{2 0 0 6}$ & $\mathbf{2 0 0 7}$ & $\mathbf{2 0 0 8}$ & $\mathbf{2 0 0 9}$ & $\mathbf{2 0 1 0}$ & $\mathbf{2 0 1 1}$ & $\mathbf{2 0 1 2}$ & $\mathbf{2 0 1 3}$ \\
\hline AIBL & 37.8 & 45.6 & 134.7 & 184.4 & 267.2 & 283.2 & 443.2 & 687.6 & 2312.1 & 704.3 \\
EIBBL & 11.3 & 22.3 & 34.4 & 71.0 & 142.8 & 245.2 & 303.6 & 374.4 & 577.1 & 288.9 \\
FSIBL & 46.4 & 62.2 & 4.9 & 33.1 & 55.7 & 55.9 & 84.3 & 101.2 & 473.2 & 71.3 \\
IBBL & 2366.9 & 3694.8 & 5381.9 & 8414.3 & 14040.4 & 19471.6 & 21462.9 & 23660.7 & 30091.5 & 28695.6 \\
SHIBL & 256.2 & 311.6 & 356.4 & 429.5 & 949.8 & 1047.8 & 615.8 & 534.0 & 292.7 & 112.4 \\
SIBL & NF & NF & NF & NF & NF & NF & NF & NF & NF & NF \\
Total & & & & & & & & & & $\mathbf{2 9 8 7 2 . 5}$
\end{tabular}

Source: Created (based on DSE Websites) \& annual reports of the sample banks. (NF=Not Found)

Table A7. Growth in remittance collection of Islamic banks, during 2004-2013

\begin{tabular}{llllllllllll}
\hline Acronyms & $\mathbf{2 0 0 5}$ & $\mathbf{2 0 0 6}$ & $\mathbf{2 0 0 7}$ & $\mathbf{2 0 0 8}$ & $\mathbf{2 0 0 9}$ & $\mathbf{2 0 1 0}$ & $\mathbf{2 0 1 1}$ & $\mathbf{2 0 1 2}$ & $\mathbf{2 0 1 3}$ & Mean & SD \\
\hline AIBL & $20.63 \%$ & $195.39 \%$ & $36.90 \%$ & $44.90 \%$ & $5.99 \%$ & $56.50 \%$ & $55.14 \%$ & $236.26 \%$ & $-69.53 \%$ & $64.6 \%$ & 0.944 \\
EIBBL & $97.35 \%$ & $54.26 \%$ & $106.40 \%$ & $101.13 \%$ & $71.71 \%$ & $23.82 \%$ & $23.32 \%$ & $54.14 \%$ & $-49.94 \%$ & $53.5 \%$ & 0.498 \\
FSIBL & $34.05 \%$ & $-92.12 \%$ & $575.51 \%$ & $68.28 \%$ & $0.36 \%$ & $50.81 \%$ & $20.05 \%$ & $367.59 \%$ & $84.93 \%$ & $123 . \%$ & 2.104 \\
IBBL & $56.10 \%$ & $45.66 \%$ & $56.34 \%$ & $66.86 \%$ & $38.68 \%$ & $10.23 \%$ & $10.24 \%$ & $27.18 \%$ & $-4.64 \%$ & $34.0 \%$ & 0.247 \\
SHIBL & $21.62 \%$ & $14.38 \%$ & $20.51 \%$ & $121.14 \%$ & $10.32 \%$ & $-41.2 \%$ & $-13.2 \%$ & $-45.19 \%$ & $61.60 \%$ & $16.6 \%$ & 0.513 \\
SIBL & - & - & - & - & - & - & - & - & - & - & - \\
\multicolumn{2}{l}{ Average growth of } & remittance of Islamic banks of Bangladesh & & & & & & $\mathbf{5 8 . 4 5 \%}$ \\
\hline
\end{tabular}

Source: Created (based on DSE Websites) \& annual reports of the sample banks

Table A8. Earnings per share (EPS) during 2004-2013

\begin{tabular}{lllllllllllll}
\hline Acronyms & $\mathbf{2 0 0 4}$ & $\mathbf{2 0 0 5}$ & $\mathbf{2 0 0 6}$ & $\mathbf{2 0 0 7}$ & $\mathbf{2 0 0 8}$ & $\mathbf{2 0 0 9}$ & $\mathbf{2 0 1 0}$ & $\mathbf{2 0 1 1}$ & $\mathbf{2 0 1 2}$ & $\mathbf{2 0 1 3}$ & Mean & SD \\
\hline AIBL & 2.64 & 3.88 & 5.02 & 3.01 & 4.83 & 4.78 & 4.14 & 3.38 & 2.38 & 2.46 & 3.65 & 1.020 \\
EIBBL & 6.08 & 6.32 & 4.35 & 4.36 & 4.16 & 4.99 & 5.33 & 2.19 & 1.98 & 1.63 & 4.14 & 1.684 \\
FSIBL & n/a & n/a & n/a & n/a & 0.74 & 1.42 & 2.33 & 1.71 & 2.04 & 1.88 & 1.69 & 0.556 \\
IBBL & 5.19 & 4.88 & 4.86 & 3.76 & 5.63 & 5.51 & 6.05 & 4.62 & 4.49 & 3.45 & 4.85 & 0.812 \\
SHIBL & n/a & n/a & n/a & 3.46 & 3.64 & 3.91 & 6.05 & 2.62 & 3.13 & 1.96 & 3.54 & 1.289 \\
SIBL & 1.43 & 0.24 & 0.98 & 1.76 & 1.72 & 1.84 & 2.14 & 1.72 & 2.29 & 1.78 & 1.59 & 0.594 \\
Average EPS & & & & & & & & & & & & $\mathbf{3 . 2 4 \%}$ \\
\hline
\end{tabular}

Source: Created (based on DSE Websites) \& annual reports of the sample banks.

Table A9. Dividend (Stock \& Cash) during 2004-2013

\begin{tabular}{llllllllllllll}
\hline Acronyms & & $\mathbf{2 0 0 4}$ & $\mathbf{2 0 0 5}$ & $\mathbf{2 0 0 6}$ & $\mathbf{2 0 0 7}$ & $\mathbf{2 0 0 8}$ & $\mathbf{2 0 0 9}$ & $\mathbf{2 0 1 0}$ & $\mathbf{2 0 1 1}$ & $\mathbf{2 0 1 2}$ & $\mathbf{2 0 1 3}$ & Mean & SD \\
\hline \multirow{2}{*}{ AIBL } & Stock & $15.5 \%$ & $26 \%$ & $35 \%$ & $20 \%$ & $30 \%$ & $30 \%$ & $26 \%$ & $21 \%$ & $17 \%$ & $13.5 \%$ & $24.3 \%$ & 0.069 \\
& Cash & - & - & - & - & - & - & - & - & - & - & & \\
\hline
\end{tabular}




\begin{tabular}{|c|c|c|c|c|c|c|c|c|c|c|c|c|c|}
\hline Acronyms & & 2004 & 2005 & 2006 & 2007 & 2008 & 2009 & 2010 & 2011 & 2012 & 2013 & Mean & SD \\
\hline \multirow{2}{*}{ EIBBL } & Stock & $40 \%$ & $30 \%$ & $25 \%$ & $25 \%$ & $26 \%$ & $35 \%$ & $35 \%$ & $14 \%$ & $10 \%$ & $11 \%$ & \multirow{2}{*}{$25.8 \%$} & \multirow{2}{*}{0.107} \\
\hline & Cash & - & - & - & $7 \%$ & - & - & - & - & - & - & & \\
\hline \multirow{2}{*}{ FSIBL } & Stock & & & & & $\ldots \ldots$ & $10 \%$ & $12 \%$ & $10 \%$ & $10 \%$ & - & \multirow{2}{*}{$10.4 \%$} & \multirow{2}{*}{0.009} \\
\hline & Cash & NL & NL & NL & NL & $\ldots \ldots$ & - & - & - & - & $10 \%$ & & \\
\hline \multirow{2}{*}{ IBBL } & Stock & $20 \%$ & $25 \%$ & $10 \%$ & $25 \%$ & $30 \%$ & $20 \%$ & $35 \%$ & $25 \%$ & $17 \%$ & $10 \%$ & \multirow{2}{*}{$25.5 \%$} & \multirow{2}{*}{0.055} \\
\hline & Cash & - & - & $15 \%$ & - & - & - & - & $7 \%$ & $8 \%$ & $8 \%$ & & \\
\hline \multirow{2}{*}{ SHIBL } & Stock & NL & NL & NL & $20 \%$ & $22 \%$ & $25 \%$ & $30 \%$ & $25 \%$ & $20 \%$ & $10 \%$ & \multirow{2}{*}{$21.71 \%$} & \multirow{2}{*}{0.062} \\
\hline & Cash & NL & NL & NL & - & - & - & - & - & - & - & & \\
\hline \multirow{2}{*}{ SIBL } & Stock & $\ldots$. & $\ldots$. & $\ldots$. & $17 \%$ & $10 \%$ & $11 \%$ & $14 \%$ & - & $10 \%$ & - & \multirow{2}{*}{$12.79 \%$} & \multirow{2}{*}{0.026} \\
\hline & Cash & $\ldots \ldots$ & $\ldots \ldots$ & $\ldots \ldots$ & - & - & - & - & $10.50 \%$ & $5 \%$ & $12 \%$ & & \\
\hline Average & & & & & & & & & & & & 20.0833 & \\
\hline
\end{tabular}

$* \mathrm{NL}=$ Not Listed.

Source: Collected from banks' declarations

Table A10. Dividend payout ratio during 2004-2013

\begin{tabular}{lllllllllllll}
\hline Acronyms & $\mathbf{2 0 0 4}$ & $\mathbf{2 0 0 5}$ & $\mathbf{2 0 0 6}$ & $\mathbf{2 0 0 7}$ & $\mathbf{2 0 0 8}$ & $\mathbf{2 0 0 9}$ & $\mathbf{2 0 1 0}$ & $\mathbf{2 0 1 1}$ & $\mathbf{2 0 1 2}$ & $\mathbf{2 0 1 3}$ & Mean & SD \\
\hline AIBL & 0.587 & 0.670 & 0.697 & 0.664 & 0.621 & 0.628 & 0.628 & 0.621 & 0.714 & 0.549 & 0.638 & 0.050 \\
EIBBL & 0.658 & 0.475 & 0.575 & 0.734 & 0.625 & 0.701 & 0.657 & 0.639 & 0.505 & 0.675 & 0.624 & 0.083 \\
FSIBL & n/a & n/a & n/a & n/a & n/a & 0.704 & 0.515 & 0.585 & 0.490 & 0.532 & 0.565 & 0.085 \\
IBBL & 0.385 & 0.512 & 0.514 & 0.665 & 0.533 & 0.363 & 0.579 & 0.693 & 0.557 & 0.523 & 0.532 & 0.104 \\
SHIBL & n/a & n/a & n/a & 0.578 & 0.604 & 0.639 & 0.496 & 0.954 & 0.639 & 0.510 & 0.652 & 0.157 \\
SIBL & - & - & - & 0.966 & 0.581 & 0.598 & 0.654 & 0.610 & 0.655 & 0.674 & 0.677 & 0.132 \\
\hline
\end{tabular}

Table A11. Year-end price earnings (P/E) ratio during 2004-2013

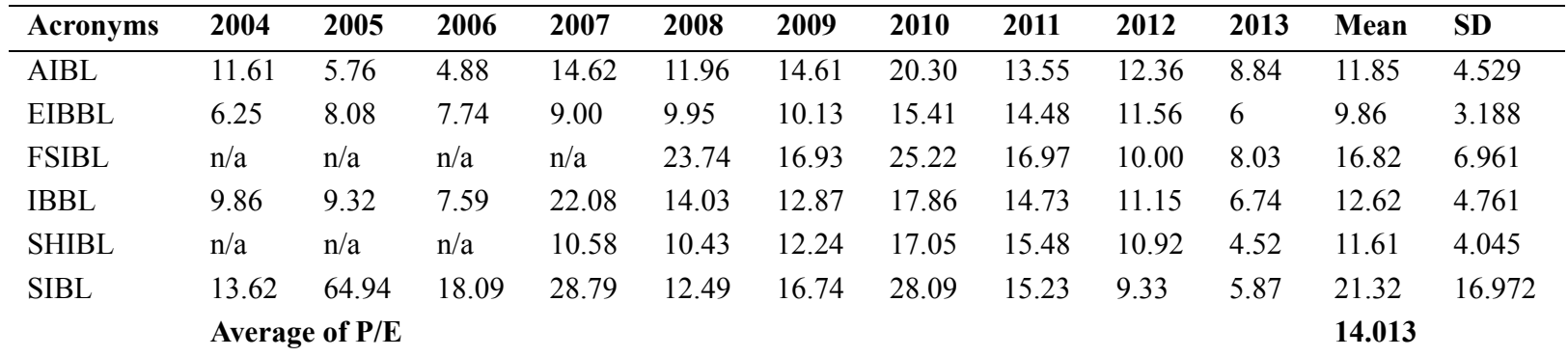

Source: Created (based on DSE Websites) \& annual reports of the sample banks.

Table A12. Net asset value (NAV) during 2004-2013

\begin{tabular}{lllllllllllll}
\hline Acronyms & $\mathbf{2 0 0 4}$ & $\mathbf{2 0 0 5}$ & $\mathbf{2 0 0 6}$ & $\mathbf{2 0 0 7}$ & $\mathbf{2 0 0 8}$ & $\mathbf{2 0 0 9}$ & $\mathbf{2 0 1 0}$ & $\mathbf{2 0 1 1}$ & $\mathbf{2 0 1 2}$ & $\mathbf{2 0 1 3}$ & Mean & SD \\
\hline AIBL & 17.86 & 20.60 & 23.26 & 19.67 & 19.55 & 19.82 & 16.42 & 16.69 & 17.46 & 17.38 & 18.87 & 2.115 \\
EIBBL & 22.30 & 21.76 & 18.16 & 21.37 & 16.63 & 19.91 & 18.22 & 15.69 & 15.74 & 17.72 & 18.75 & 2.460 \\
FSIBL & n/a & n/a & n/a & n/a & 11.03 & 12.45 & 12.81 & 13.23 & 15.15 & 15.65 & 13.39 & 1.733 \\
IBBL & 30.80 & 29.72 & 29.96 & 31.15 & 29.59 & 32.55 & 31.72 & 27.59 & 31.70 & 29.92 & 30.47 & 1.421 \\
SHIBL & n/a & n/a & n/a & 16.89 & 16.05 & 17.98 & 19.76 & 17.78 & 17.36 & 16.42 & 17.46 & 1.229 \\
SIBL & 15.65 & 15.78 & 25.90 & 16.57 & 14.26 & 13.20 & 14.05 & 14.64 & 15.88 & 15.78 & 16.17 & 3.571 \\
\hline
\end{tabular}

Source: Created (based on DSE Websites) \& annual reports of the sample banks.

\section{Copyrights}

Copyright for this article is retained by the author(s), with first publication rights granted to the journal.

This is an open-access article distributed under the terms and conditions of the Creative Commons Attribution license (http://creativecommons.org/licenses/by/3.0/). 